\title{
Triptorelin in androgen depravation therapy of advanced prostate cancer
}

\author{
Mieszko Kozikowski, Jakub Dobruch \\ Urology Clinic of Medical Postgraduate Education Center, \\ Department of Urology, Independent Public Hospital them. prof. Witold Orlowski, \\ Medical Postgraduate Education Centre
}

Correspondence:

Mieszko Kozikowski

Urology Clinic of Medical Postgraduate Education Centre, Department of Urology, Independent Public Hospital them. prof. W. Orlowski,

Medical Postgraduate

Education Centre

00-416 Warsaw,

Czerniakowska 231, Poland

phone: (+48) 792-272-890

e-mail:mieszkokozikowski9@ gmail.com

Received: 6.09.2019 Accepted: 10.10.2019

DOI: 10.24292/01.OR.219101019 Copyright $\odot$ Medical Education. All rights reserved.

\section{ABSTRACT}

Triptorelin as the luteinizing hormone releasing hormone (LHRH) analogue has its own place among other available forms of androgen-depravation therapy (ADT) of locally advanced and metastatic prostate cancer (PCa). Nowadays, in times of development of new therapies in castration-resistant PCa, ADT remains the back bone therapy, which may be supplemented with one of novel drugs. The results of basic research indicate, that apart from the main mechanism of action based on lowering a testosterone concentration to the castration level, triptorelin may have a direct inhibitory effect on tumor cells. Formulations of tryptorelin are available to administer as 1-month, 3-months and 6-months sustained-release forms that may be given intramuscularly or subcutaneously. Constant concentration of triptoreline is maintained by using special microspheres in drug production. Pharmacokinetic and pharmacodynamic properties of particular forms were extensively tested, which allows for safe usage and retain of predictable and high efficacy.

Indicators of effective ADT are fast reduction and maintenance of the state of castration. This phenomenon translates into a decrease of the prostate-specific antigen and longer survival. Triptorelin successfully meets these objectives based on a number of phase I-III studies. There is a noticeable lack of comparative studies on effectiveness of particular ADT forms. This may stem from an assumption, that all LHRH analogues demonstrate similar effectiveness because of the class effect. However, some evidence highlight significant differences in efficacy among these drugs. Triptorelin compares especially favourably, particularly as a drug reducing the testosterone level to the lower recommended values (<20 ng/dl).

Side effect profile during the therapy with triptorelin is largely the result of inhibition of the hypothalamic-pituitary-testicular axis. Hormonal disturbances linked to hipoandrogenism cause changes in lipid metabolism and glucose tolerance, which may influence the cardiovascular risk. This article is a review of key reports regarding triptorelin and a summary of the role that triptorelin plays in contemporary ADT in advanced PCa.

Key words: advanced prostate cancer, androgen depravation therapy, triptorelin 


\section{INTRODUCTION}

\section{Advanced prostate cancer}

Prostate cancer ( $\mathrm{PCa}$ ) belongs to the most common cancers among men. In 2018 PCa was detected in 1.28 men and over 350 thousand deaths were registered of this cause [1]. It is the second most common malignant neoplasia in men and the fifth most common cause of cancer-specific death. The widespread introduction of the prostate-specific antigen (PSA) in the nineteen-nineties and the aging of population highly influenced the number of new PCa cases [2]. As a result of the first phenomenon the percentage of patients, in whom PCa were limited to the prostate gland, which means in whom the radical treatment could be introduced, drastically increased, and the percentage of patients with advanced PCa markedly decreased [3]. However, likewise other effective screening tests, the introduction of PSA led to a general increase in the PCa detection [4], whereby the scale of detection growth became worrisome. That phenomenon provided the basis for later limitation of PSA testing and most likely prompted a growth of new PCa diagnoses in the metastatic stage, particularly among white men in the 64-75 age group [5].

\section{BASICS OF ANDROGEN DEPRAVATION THERAPY}

A unique feature of $\mathrm{PCa}$ is hormone-sensitivity, which means the dependance on male sex hormones, particularly testosterone, in the growth of $\mathrm{PCa}$ [6]. This phenomenon formed the basis for the development of hormonal treatment, which has remained the mainstream form of management in patients with metastatic PCa for over 50 years [7]. The basic aim is to decrease markedly serum testosterone concentrations (androgen deprivation therapy, ADT). This aim may be reached surgically by performing bilateral orchiectomy (castration) or pharmacologically by administering drugs that act on various levels of the hypothalamic-pituitary-testicular axis. In men who underwent orchiectomy, testosterone levels are typically $<20 \mathrm{ng} / \mathrm{mL}(<1.0 \mathrm{nmol} / \mathrm{l})$, whereby still a testosterone level $<50 \mathrm{ng} / \mathrm{dl}(<1.7 \mathrm{nmol} / \mathrm{l})$ is regarded as the castrate level [8].

Several nonsurgical methods to achieve the castration are known. They are luteinizing hormone-releasing hormone (LHRH) analogues, LHRH antagonists and estrogens, which use is currently limited [8]. Even in the era of the development of new systemic therapies in metastatic PCa, ADT remains the indispensable component of such treatment [9].

\section{INDICATIONS FOR ANDROGEN DEPRAVATION THERAPY}

Defining the disease as advanced in relation to PCa may concern two situations: a locally advanced tumor extending beyond borders of the gland ( $\geq \mathrm{T} 3$ ) or metastatic disease (M1). ADT may be applied both situations. In case of the locally advanced $\mathrm{PCa}$, in men disqualified from any form of local treatment, ADT may be administered if PSA exceeds $50 \mathrm{ng} / \mathrm{mL}$ and PSA doubling time (PSAD) is shorter than 12 months or in case of poorly differentiated neoplasia [8]. With regard to systemic disease, detection of metastases, including nodal metastases (N1), enables to start ADT.

Throughout many years ADT has remained the main and the only form of therapy in patients with metastatic PCa. Nowadays, in the era of the development of treatments combined with the next-generation antiandrogens, docetaxel chemotherapy or abiraterone, ADT is continued and forms a background for novel drugs. It is then called the backbone therapy.

ADT is also indicated in therapy of men with intermediate- and high-risk PCa as a treatment accompanying external beam radiotherapy (EBRT). ADT is then conducted for 4-6 months in patients with intermediate PCa or for 18-36 months in patients with high-risk PCa. Based on numerous studies, the combination of ADT and EBRT was proven to have a synergistic effect [10].

\section{Mechanism of action of LHRH analogues}

The main purpose of using LHRH analogues in the treatment of patients with $\mathrm{PCa}$ is to suppress the hypothalamic-pituitary-testicular axis. The main mechanism of action of LHRH analogues is the desensitization of LHRH receptors on the surface of pituitary neurons, which results in a decrease of secretion of luteinizing hormone (lutropin, LH) affecting Leydig cells, that produce testosterone in testicles, and as a consequence, decreases testosterone levels. LHRH agonists initially stimulate and then inhibit pituitary LHRH receptors. This initial step is caused by an agonistic activity towards the LHRH receptor and prompts a transient flare-up of serum testosterone level. For this purpose administration of LHRH analogue during the first few days needs a special attention, because as a result of transient increase of a testosterone level, it may aggravate symptoms of advanced neoplastic disease. Addition of antiandrogen, for example bicalutamide or flutamide, to LHRH analogue used for the first time, allows to avoid adverse effects of testosterone flare-up [8].

LHRH particle is a peptide built of 10 amino acids of a short half-life. Drugs affecting LHRH receptor, even though they have 
a corresponding peptide structure, contain a modification of particular amino acids, usually in $6^{\text {th }}$ position. Such modification prolongs the half-life of a molecule and its strength of influence on the receptor. LHRH analogues are characterized by high affinity toward receptors of gonadotropin-releasing hormone $(\mathrm{GnRH}$, LHRH) placed on the surface of cells of the anterior lobe of the pituitary. cDNA gene for the receptor codes a transmembrane protein from the G-protein family and its mRNA is expressed in the pituitary, the ovary, breast glands, testicles and the prostatic gland [11].

LHRH is synthesized by hypothalamic neurons and undergoes secretion in pulse-like manner. After release it reaches the ante- rior lobe of the pituitary through the hypothalamic-hypophyseal portal circulation. GnRH stimulates there a secretion of gonadotropic hormones: LH and follicle-stimulating hormone (folliculotropin, FSH), that regulate the hormonal activity of gonads [12]. Pituitary cells treated with LHRH analogue react paradoxically with desensitization and down-regulation of $\mathrm{GnRH}$ receptors, which leads to a significant reduction of gonadotropins release. This phenomenon is explained by a difference of the structure of LHRH receptor, which contains several potential post-translational modification sites. A unique element of this receptor, in comparison to other $\mathrm{G}$-proteins with seven-domains structure, is the lack of cytoplasmic domain in C-terminal end, which might be responsible for an exceptional ability to desensitize (fig. 1).

FIGURE 1.

Topographic structure of the luteinizing hormone releasing hormone receptor including the amino acid sequence. Similar to other $\mathrm{G}$ proteins, the receptor contains seven transmembrane domains. Lack of cytoplasmic domain at C-terminal position. Potential post-translational modification sites are marked. Amino acids are described by a single letter code. Generated in the Protter program [82].

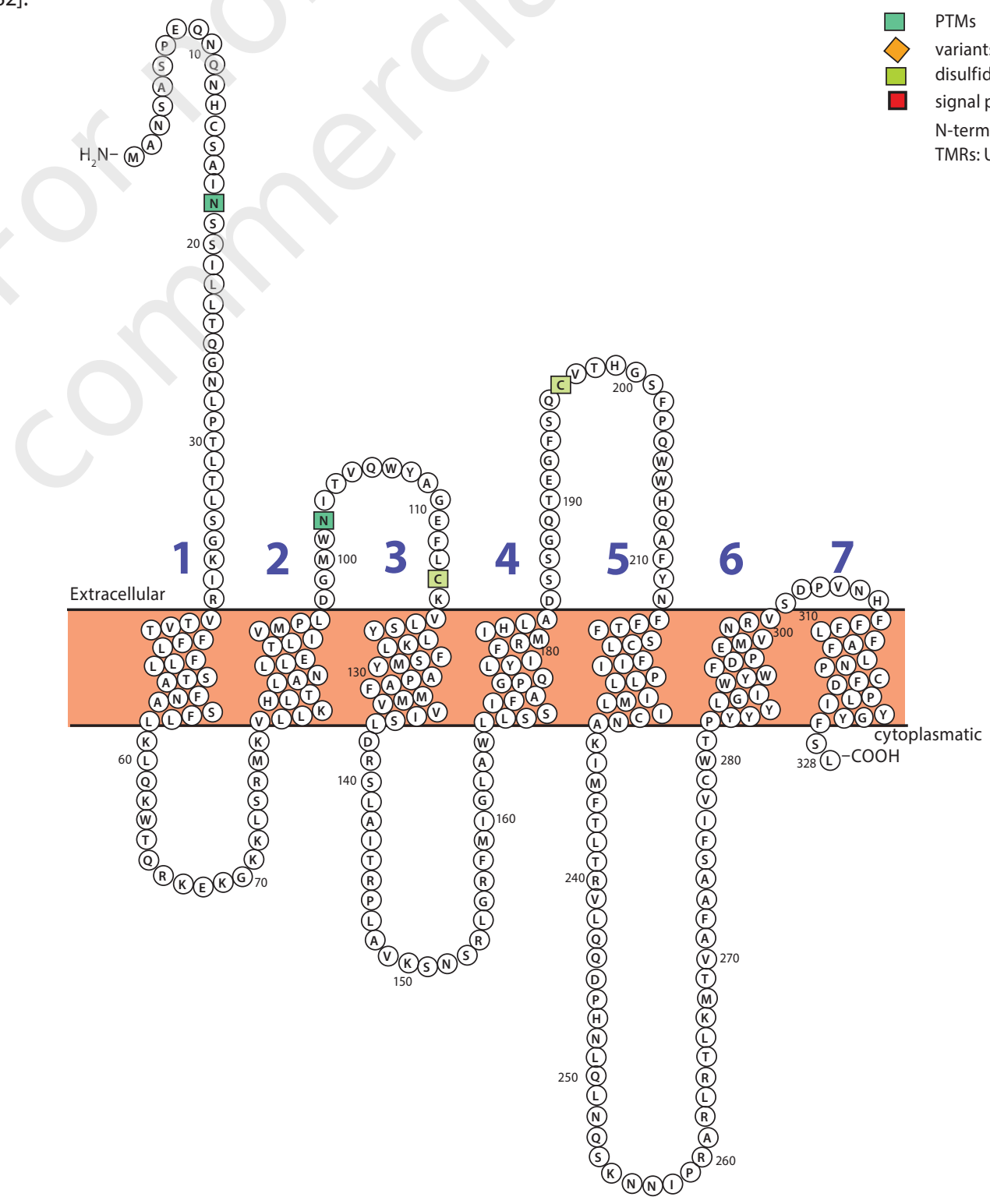




\section{ROLE OF TRYPTORELIN IN CURRENT ANDROGEN DEPRAVATION THERAPY}

\section{Triptorelin sustained-release formulations}

Triptorelin is one of the mostly used LHRH analogues in ADT. As mentioned before, LHRH analogues, because of their peptide structure, are characterized by short half-life. Due to a need for the constant maintenance of the castrate level of testosterone, sustained-release formulations (SR) were developed. In Poland, there are two sustained-release formulations of triptorelin available in different dosages: Diphereline SR (doses: 3.75 mg, 11.25 mg and 22.5 mg, Ipsen Pharma) and Decapeptyl Depot (3.75 mg dose, Ferring $\mathrm{GmbH}$ ) [13].

SR formulations allow for convenient administration of drugs every few weeks or months. Triptorelin in doses 3.75 mg, 11.25 $\mathrm{mg}$ and $22.5 \mathrm{mg}$ is used on a monthly, three-monthly and six-monthly basis, respectively. In these formulations triptorelin is in a form of triptorelin pamoate or triptorelin acetate. SR formulations release triptorelin slowly, whereas the subcutaneous form differs in this respect from the form administered intramuscularly [14]. Triptorelin administered subcutaneously reaches the blood through the lymph, which causes some delay in reaching the therapeutic level in comparison to intramuscular administration. In the latter case, triptorelin directly reaches the blood (the first-order kinetics of absorption model). Despite the differences in pharmacokinetics, both routs of administration are equally effective in respect of reaching the castrate level of testosterone [15].

To obtain a steady pace of triptorelin release form the controlled-release formulations it was necessary to develop special microspheres. They contain triptorelin particles incorporated inside into a matrix built of biodegradable copolymer of lactic and glycolic acid (poly[lactide-co-glycolide], PLGA). A gradual enzymatic decomposition of polymer in vivo causes the release of triptorelin through microcanals, that emerge as a result of this process. At the same time, the microspheres stabilize and protect triptorelin from a premature decomposition and enable the gradual release of drug in clearly specified amounts in assumed time [16].

\section{PHARMACODYNAMIC AND PHARMACOKINETIC PROPERTIES OF TRIPTORELIN}

Tryptorelin (D-Trp-6-LHRH; H-Pyr-His-Trp-Ser-Tyr-D-Trp-Leu-ArgPro-Gly-NH2) is a synthetic oligopeptide built from ten amino acids analogously to LHRH, but contrary to the native hormone, in sixth position instead of glycine occurs D-tryptophan [17]. This modification results in a stronger agonistic activity and a longer half-life (fig. 2). Triptorelin, as an agonist, has about 100 times greater affinity to the LHRH receptor than the endogenous counterpart [18].

After intramuscular administration of triptorelin acetate (Diphereline SR 3.75 mg, Decapeptyl Depot $3.75 \mathrm{mg}$ ) in the lowest dose, the maximum concentration of triptorelin in serum is observed within 24 hours. This results from the release of an active component from the surface of the microspheres [19, 20]. Afterwards follows a phase of sustained-release of the analogue for 4 weeks. Intramuscular injection of tritorelin pamoate (Diphereline SR $11.25 \mathrm{mg}$, Diphereline SR $22.5 \mathrm{mg}$ ) results in reaching the maximum concentration of triptorelin in blood as soon as in the first

FIGURE 2.

Comparison of the amino acid sequences of the most commonly used luteinizing hormone releasing hormone (LHRH) analogues. The sixth position in triptorelin is marked, in which, in contrast to the native hormone, D-tryptophan is present instead of glycine. Amino acids are described by a single letter code. Generated in the Protter program [82].

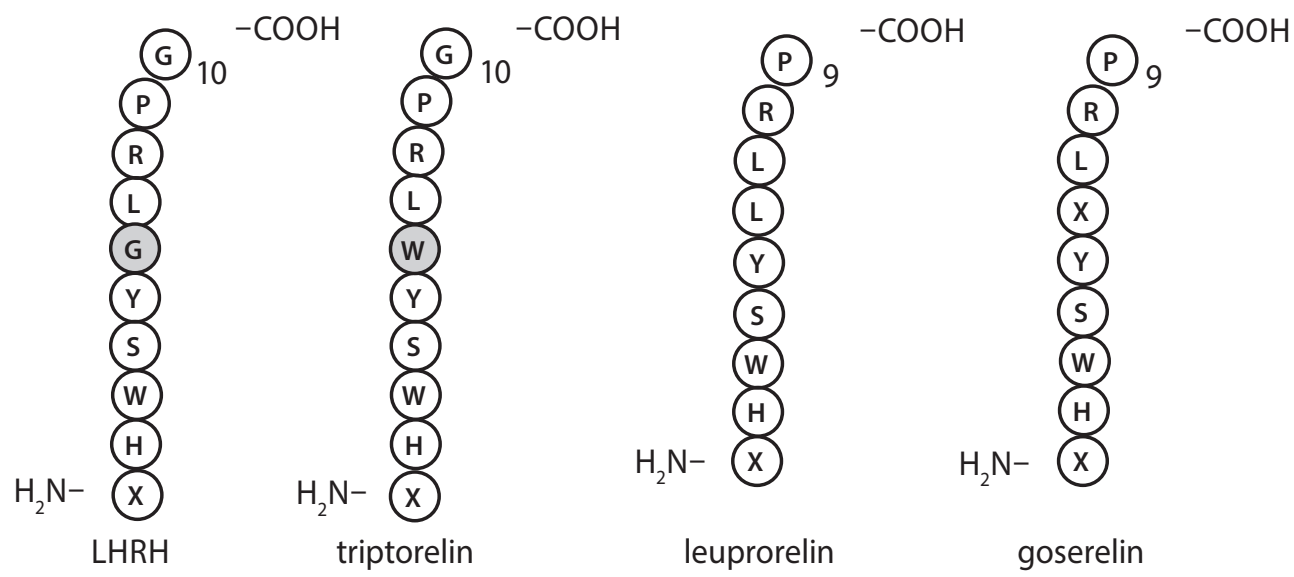


3 hours from administration [21, 22]. During the first 4 weeks there is a slow decrease of triptorelin level, which then after 1 month is maintained at a constant level for the next 2 months. The castrate level of testosterone is reached after around 3 weeks and is maintained as a long-lasting low level.

As mentioned earlier, the agonistic activity of triptorelin towards the $\mathrm{LHRH}$ receptor causes at the beginning a transient increase of LH level in blood and corresponding increased synthesis of testosterone (flare-up). Time lapsing from administration to achievement of maximum testosterone level and its subsequent decrease depends from the dose of triptorelin used. As a result of the constant release of the drug, a decrease in LHRH level is observed in serum over time. Maximal antiandrogen effect, expressed in a decrease in a testosterone level, appears after around 2 to 4 weeks. In that time, a serum testosterone reaches the values typical for men, who underwent orchiectomy. In animal studies was proven, that after intramuscular administration of triptorelin acetate in a from of the biodegradable microspheres of four-week sustained-release, a testosterone level reaches the castrate level within 5 days from injection and is not changed until the next administration of the drug [23]. In that model it was also noted, that a triptorelin level increases shortly after administration - within the first 30-60 minutes and then it decreases to rise again in the $1^{\text {st }}$ or the $2^{\text {nd }}$ day. After that time it gradually decreases and, starting from the $4^{\text {th }}$ day after the drug administration, stays on a relatively constant level until the $28^{\text {th }}$ day. These observations confirm earlier studies on dosing of SR formulations, in which the first increase of triptorelin level is accompanied by an increase of LH level reaching the maximum level after 60 minutes and staying on that level for slightly over 24 hours [24]. Consequently, the first dose of triptorelin causes a transient flare-up of testosterone level, after which a sudden drop in testosterone to the castrate level occurs and lasts until $28^{\text {th }}$ day.

The initial flare-up of testosterone after administration of triptorelin, which is a characteristic feature of all LHRH analogues, may be responsible for an exacerbation of symptoms related to the local advancement of PCa or metastases in selected patients. In particular: aggravation of symptoms of bladder outlet obstruction, bone pain or even symptoms of spinal cord compression. Therefore, the first administration of any analogue should be preceded by two-week therapy with antiandrogen, for example flutamide or bicalutamide [8]. Such a proceeding should prevent from undesirable adverse effects of a transient increase of a testosterone level in the blood.
Triptorelin is eliminated by both the liver and the kidneys. No metabolites of triptorelin have been identified so far and an enzymatic decomposition of this particle has not been fully explained [19]. Triptorelin is not binding to serum proteins in concentrations used in clinical practice. Pharmacokinetics of triptorelin after intravenous injection is well described by the three-compartment model with estimated half-lives of 6 minutes, 45 minutes and 3 hours in compartments represented by the plasma, the highly perfused tissues and the scarcely perfused tissues, respectively [19]. Pharmacodynamic and pharmacokinetic relations of the hypothalamic-pituitary-testicular axis are identified by the model describing LH and testosterone levels after the intramuscular administration of triptorelin in $3.75 \mathrm{mg}$ dose [14]. Pharmacodynamics of this axis is exceptionally nonlinear, which results from numerous interactions and negative-feedback type regulations of substance secretion.

There was also developed a pharmacokinetic/pharmacodynamic model, that include competitive, agonistic activity of triptorelin versus the endogenous hormone and reversible binding to the receptor, which leads to a testosterone flare and triggers mechanisms of down-regulation and reduce the number of the receptors [25]. The model is applicable for every type of sustained-release formulation after subcutaneous or intramuscular administration. It describes a complete profile of response and clinically significant parameters as a duration of castration and the highest testosterone level. Investigations are underway to establish a perfect pharmacokinetic profile, that would limit to the minimum the flare-up phenomenon and provide fast (within 3 weeks from administration) and the long-lasting castration.

\section{TRIPTORELIN IN PRECLINICAL STUDIES}

Beside the mentioned above, common for all LHRH analogues, mode of action limiting the progression of PCa by affecting the hypothalamic-pituitary-testicular axis, the antitumor effect of triptorelin may also be based on mechanisms not related to lowering of testosterone levels. During the first day after administration of triptorelin in men with advanced $\mathrm{PCa}$, focal regressive changes in the tumor tissue can be already detected, indicating the phenomenon of apoptosis (programmed cell death). It is possible that some cancer cells express the LHRH receptor on their surface, which allows a direct influence of the LHRH analogue on these cells [26].

The proposed molecular mechanism of triptorelin action is the activation of tyrosine phosphatases, whose activity reverses growth promotion caused by oncogen-encoded tyrosine kinases 
in tumor cells [27]. At least in part, the clinical effect of attachment of triptorelin to the LHRH receptor may be due to inhibition of epithelial growth factor (EGF) tyrosine kinase activity, thereby inhibiting tumor growth (fig. 3). Triptorelin appears to reverse the protein phosphorylation initiated by EGF, which under normal conditions mediates signaling for growth stimulation $[27,28]$ The phenomenon of down-regulation of $\mathrm{LHRH}$ receptors also occurs at the level of cancer cells. Triptorelin reduces the concentration of EGF and LHRH receptors on the surface of PCa cells [29].

FIGURE 3.

A simplified scheme depicting mechanism of action of tryptorelin and interaction with epithelial growth factor tyrosine kinase (EGF). Description in text.

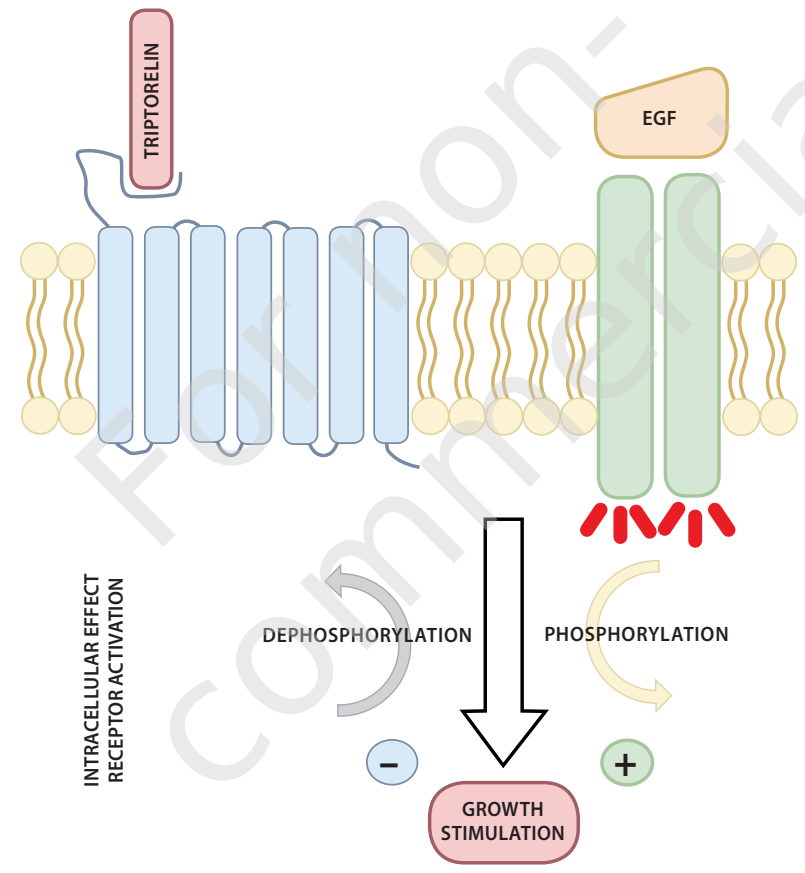

The number of LHRH receptors and the expression of the corresponding mRNA are reduced by more than $20 \%$ after 4 weeks from the beginning of treatment [30]. The very presence of LHRH receptors on the surface of cancer cells - this phenomenon does not occur within the normal prostate - is interesting because the gene for the LHRH receptor has anti-tumor activity. The number of dividing cells in androgen-independent PCa lines is reduced under the influence of triptorelin [28]. This phenomenon resembles patients with castration-resistant prostate cancer (CRPC), in whom LHRH analogues are being continued. This is explained by the disorder of the autocrine feedback loop of EGF and its receptor by dephosphorylation. At the same time, a similar suppression of growth of PCa cell lines treated with the GnRH receptor antagonist was noted [31]. The differences in direct anti-tumor activity of LHRH agonists and antagonists were explained by the presence of two different LHRH receptor subtypes. Triptorelin is only active on the GnRH-I receptor [32].

In addition to the activity at the level of the central nervous system described above, triptorelin also exerts a direct inhibitory effect on cancer cells through specific receptors on tumor cells leading to a significant reduction in tumor growth [11, 33, 34]. Similar to the pituitary gland, LHRH analogue leads to receptor desensitization after some time. Morphological and histological changes are visible effects of interaction at the molecular level. Administration of triptorelin reduces the mass of the testicles, the prostate and seminal vesicles [35, 36]. In animal models, a significant reduction in tumor volume and mass is noted, which is the result of a decrease in the number and a significant reduction of epithelial cell density by atrophy of the glandular epithelium and an increase in the relative proportion of stromal connective tissue $[36,37]$. Histological changes in the prostate after triptorelin administration include a loss of glandular architecture and a reduction in the number of stromal cell mitoses [38]. Regressive changes of the epithelial component are accompanied by fibrosis. Epithelial cells respond more to testosterone deficiency than stromal cells [39]. The glands are deformed, the epithelial cover is thinned, and the volume of substance secreted by the glands is reduced. Cell nuclei contract and take on the pyknotic appearance with highly condensed chromatin, and the mitotic activity becomes very low. As a result of these phenomena, the prostate becomes atrophic. Ultimately, the histological changes during triptorelin treatment correspond to those seen in surgically castrated animals.

\section{THE EFFICACY OF TRIPTORELIN IN CLINICAL STUDIES}

The most important indicator for effectiveness of LHRH analogue used in ADT is its ability to reduce and to maintain the castrate level of testosterone in the blood. In clinical studies the most credible endpoint in terms of oncologic outcome is overall survival of men who underwent particular treatment. However, in prostatic neoplasia, because of the limitations resulting from a slow natural course of disease, several surrogate endpoints are used with PSA among others.

Initial studies conducted in the nineties of the last century have proven, that triptorelin in sustained-release formulation is a safe and efficient drug in advanced PCa [40-42]. Phenomena observed in the preclinical studies were confirmed in men with PCa with nodal metastases or bone metastases: a remarkable decrease in a serum testosterone to the castrate level and a decline of $\mathrm{LH}$ 
level proving the long-acting suppression of hypothalamic-pituitary-testicular axis. In transrectal ultrasound (TRUS) a shrinkage of tumor mass for over 50\% was observed [41]. In imaging studies, a reduction of bone metastases was noted in $17.5 \%$ of cases. In the majority of patients (71.9\%) a reduction in symptoms was also observed, particularly a reduction in bone pain.

After the development of a sustained-release, three-monthly formulation (dose of $11.25 \mathrm{mg}$ ) its pharmacokinetic and pharmacodynamic properties were evaluated in 14 men with advanced PCa in a phase I-II trial [43]. After single injection the castrate level of testosterone was achieved after the mean of 22 days and remained on this level for 3 months of therapy. The evidence for an equal efficacy of one-month and three-month triptorelin formulations regarding the ability to lower testosterone levels provides the randomized trial, into which 126 men with advanced PCa were included [44]. The castration was achieved in less than three weeks in $96 \%$ and $98 \%$ of men, respectively, whereby an administration of both those formulations resulted in the same lowering of $\mathrm{LH}$ levels and a testosterone level. A decrease of PSA after 3 months of therapy in $91.7 \%$ and $91.0 \%$ of men, respectively proves identical efficacy. Therefore, no differences were found regarding pharmacologic efficacy between one-month and three-month sustained-release formulations. At the same time, symptoms referring a local advancement of the disease or metastases improved or at least stayed the same in both groups.

The efficacy of treatment with six-month release formulation was proven in the phase III trial, that lasted twelve months [45]. 120 men with advanced PCa were included into this study, among which in $97.5 \%$ the castrate testosterone level was registered before the end of the first month and $93.0 \%$ had maintained this level for a year after the first administered dose. In a few of patients, in which testosterone escape was encountered above the castrate level, no PSA increase was noted. Only in three patients the therapeutic failure defined as an increase in PSA was recognized. Pharmacodynamic properties of sustained-release triptorelin were similar to other formulations. In line with the expectations, the first dose led to an increase of a testosterone level with subsequent drop to the castrate level about 19 days after the beginning of treatment. In almost every men (98.3\%) desensitization of the hypothalamic-pituitary-testicular axis occurred, which was reflected by the lack of increase of LH level after administration of the second dose. A relative drop of PSA level was $97 \%$ and $96 \%$ after six and twelve months from the beginning of therapy, accordingly. This study confirmed the efficacy of six-month triptorelin, that combines the ease of administra- tion with maintaining the drug's ability to cause the castration and to lower PSA.

As mentioned above, an optimal aim of ADT should be to lower a testosterone level $<20 \mathrm{ng} / \mathrm{dl}$ [46]. A multicenter, prospective study, into which 126 patients treated with triptorelin dose $11.25 \mathrm{mg}$ demonstrated, that this analogue works well in reaching the lower testosterone levels [47]. A testosterone level $<20 \mathrm{ng} / \mathrm{dl}$ was achieved in $90.0 \%$ of men after over 6 months form the beginning of treatment. The castrate level of testosterone according to the old definition was achieved in $97.6 \%$ of men after the first month of treatment and was maintained in almost all (96.6\%) a month after the next dose. The mean reduction of $64.2 \%$ and $96.0 \%$ of PSA levels was achieved when measuring a concentration of that marker in $4^{\text {th }}$ and $26^{\text {th }}$ week of treatment.

These results prompted researchers to reach for retrospective data from nine previous studies that involved a total of 920 men, that were treated with one-, three- and six-month sustained-release triptorelin and the therapy lasted on average from two months to a year. The testosterone level $<20 \mathrm{ng} / \mathrm{dl}$ currently recommended by EAU was considered adequate. Starting from the third month of treatment, the lower castrate level of testosterone was achieved in over $90 \%$ of men. Formulations differed in their effectiveness in achieving lower testosterone levels. On average, the lowest values measured at the end of the study were achieved using one-month $(2.9 \mathrm{ng} / \mathrm{dl})$, then three-month $(5.0 \mathrm{ng} / \mathrm{dl})$ and six-month release formulation $(8.7 \mathrm{ng} / \mathrm{dl})$. In the vast majority of patients, sustained-release formulations lowered a testosterone level to the lower recommended value [48].

A verification of the results presented above was carried out in a phase IV multicenter study, in which 41 men with advanced PCa were treated with triptorelin $11.25 \mathrm{mg}$ preceded by $50 \mathrm{mg}$ bicalutamide, which was continued for a month to prevent the negative effects of a transient testosterone flare [49]. Very low testosterone levels were observed in $97.5 \%$ of men after three months and in all patients after the next 3 months. PSA decreased to the mean of $10.4 \mathrm{ng} / \mathrm{mL}$ after three months and 11.61 $\mathrm{ng} / \mathrm{mL}$ after six months of treatment, which corresponded to a 99.2\% reduction in PSA. Using appropriate questionnaires, it was shown that symptoms resulting from a local disease progression (dysuria, hematuria, urinary retention or incontinence) and distant metastases (bone pain) improved during triptorelin treatment. Overall health status also improved in all areas studied: physical, emotional, cognitive and social functioning as well as social roles. In particular, symptoms such as fatigue, pain and loss 
of appetite have improved significantly. This study highlights the effectiveness of triptorelin therapy not only in terms of objective indicators, such as testosterone or PSA levels, but also in terms of subjective symptoms.

A unique feature of triptorelin preparations is also the possibility of subcutaneous administration, which has been proven to have no influence on its effectiveness. In lasting a half-year German multicenter study, 52 men received triptorelin $3.75 \mathrm{mg}$ subcutaneously or intramuscularly [50]. Assuming a testosterone concentration as an indicator of the effectiveness of treatment, both routes of administration resulted in a decrease in testosterone levels and its maintenance at the castration level in all patients until the end of the study.

Recently, attempts have also been made to establish new markers, other than PSA, that could be used to assess the response for treatment with triptorelin. The Triptocare study evaluated PCA3 (prostate cancer antigen-3) and TMPRSS2-ERG tests, which are standard in PCa diagnostics, and were measured at the beginning and after 6 months of treatment of men with advanced PCa with triptorelin with a six-month release period [51]. The percentage of men with undetectable PCA3 titers increased during treatment from $12.1 \%$ to $32.0 \%$, while the percentage of men with a positive TMPRSS2-ERG test decreased during treatment from 46.3\% to $9.1 \%$. Meanwhile, mRNA for PSA was undetectable in $80.9 \%$ of men at the end of the study. After six months of treatment, the mean PSA and the mean testosterone were $1.2 \mathrm{ng} / \mathrm{mL}$ and $12 \mathrm{ng} / \mathrm{dl}$, respectively. PCA3 and TMPRSS2-ERG tests are unfortunately useless in assessing the response to treatment in this patient population due to the large (> 10\%) percentage of patients with these tests being initially undetectable. Nevertheless, it turns out that among the participants of the Triptocare study, after 3 years of starting treatment, patients with a positive PCA3 result had more than nine times lower relative risk of progression to CRPC, regardless of whether continuous or intermittent ADT was used [52].

Hormonal treatment with triptorelin has been studied in special clinical situations. Sometimes replacing the LHRH analogue, while facing the progression of advanced $P C a$ to $C R P C$, results in a transient PSA response. A retrospective study included 36 men with PSA progression despite effective ADT, who received triptorelin at a dose of $11.25 \mathrm{mg}$ every 3 months as a result of this progression [53]. In nine patients (25\%) PSA decreased by more than $50 \%$, and in three more (14\%) PSA did not change. Progression-free survival was 53 weeks compared to 28 weeks for non-responders for the change of analogue. Despite encourag- ing results, it should be emphasized that due to widely available new forms of treatment for patients with CRPC, substitution of the LHRH analogue is no longer recommended [8].

Recent studies have confirmed the effectiveness of one-month triptorelin formulation in combination with cyproterone acetate in intermittent ADT (intermittent androgen-depravation therapy [iADT]) [54]. In a randomized trial, it was proven that iADT conducted in this way is no less effective (non-inferior) than continuous ADT in terms of the overall survival of patients while maintaining sexual performance in a larger percentage of men undergoing this treatment.

To summarize, the efficacy of triptorelin has been confirmed in prospective, unblinded, multicenter, single-arm phase I-III studies. Pharmacologically, triptorelin has a characteristic for LHRH analogues activity on LH, testosterone and PSA levels. In addition, studies have proven that all available sustained-release forms have almost the same effectiveness in achieving these goals.

\section{COMPARISON OF THE EFFECTIVENESS OF TRIPTORELIN WITH OTHER FORMS OF THERAPY}

The first attempts to compare the effectiveness of triptorelin with other forms of ADT in achieving remission in patients with advanced PCa indicated a possible advantage over orchiectomy and estrogens [55]. Bilateral orchiectomy causes a reduction in testosterone levels to values that define its castration level. A number of studies have been carried out comparing the effectiveness of surgical treatment and ADT with the use of triptorelin. Attempts were made to clarify whether the mechanism of action of triptorelin, which, in addition to lowering testosterone, directly affects tumor cells, leads to additional benefits. It is also understood that both interventions result in different phenomena in terms of endocrine disorders: after the use of triptorelin, $\mathrm{LH}$ and FSH secretion are suppressed, while after orchidectomy gonadotropin levels are permanently elevated.

In a randomized clinical trial involving 130 men, orchidectomy was compared with one-month triptorelin formulation [56-58]. One month after the beginning of therapy, a comparable castration level of testosterone was achieved, which was maintained in both groups until the end of the study. There has also been a trend towards less psychological burden of treatment among men receiving triptorelin. In terms of safety, in three patients treated with triptorelin, an increase in the severity of symptoms (lymphoedema, bone pain) was noticed, which could indicate 
a temporary flare in testosterone levels at the beginning of treatment. The symptoms resolved within the next two months. It is worth noting that patients who experienced progression despite orchiectectomy were given triptorelin. One man experienced remission as a result of this treatment. During the almost two-year study, there was no significant difference in response to treatment, PCa progression, or overall survival. These observations confirmed the results of a recent, randomized study comparing subcapsular orchiectomy and ADT based on six-month release triptorelin [59]. After 12 months, it was noted that patients treated with triptorelin showed an average of $29 \%$ lower testosterone levels than men, who underwent subcapsular orchiectomy (fig. 4). Although the castrate level of testosterone was achieved in all men, lower recommended testosterone levels $(<20 \mathrm{ng} / \mathrm{dl})$ were maintained in all patients receiving triptorelin, but only in $87 \%$ of men, that underwent surgery. The above mentioned studies indicate that the treatment with long-release triptorelin is a safe and effective alternative to orchiectomy. Compared with subcapsular orchiectomy, triptorelin treatment results in a re- duction of testosterone to lower recommended values in a larger proportion of patients.

There are few studies available that directly compare the efficacy of individual LHRH analogues in the treatment of advanced PCa. This may in part be due to the assumption that they show to some extent the class effect. However, there is not enough evidence that only because of the similarity of their chemical structure and the hypothetical mechanism of action, the pharmacological effects of each of the available LHRH analogues will be identical [60]. Preliminary studies comparing monthly release tryptorelin and leuprorelin formulas gave conflicting results $[61,62]$.

Important observations were provided by a multicenter, randomized clinical trial of 284 men, in which the monthly release triptorelin (3.75 mg dose) and leuprorelin (7.5 mg dose) were compared in terms of efficacy in obtaining and maintaining the castration level of testosterone in men with advanced PCa [63].

\section{FIGURE 4.}

Median testosterone levels in patients during triptorelin treatment (red squares) and undergoing subcapsular orchidectomy (blue circles) at successive intervals. Modified after [59].

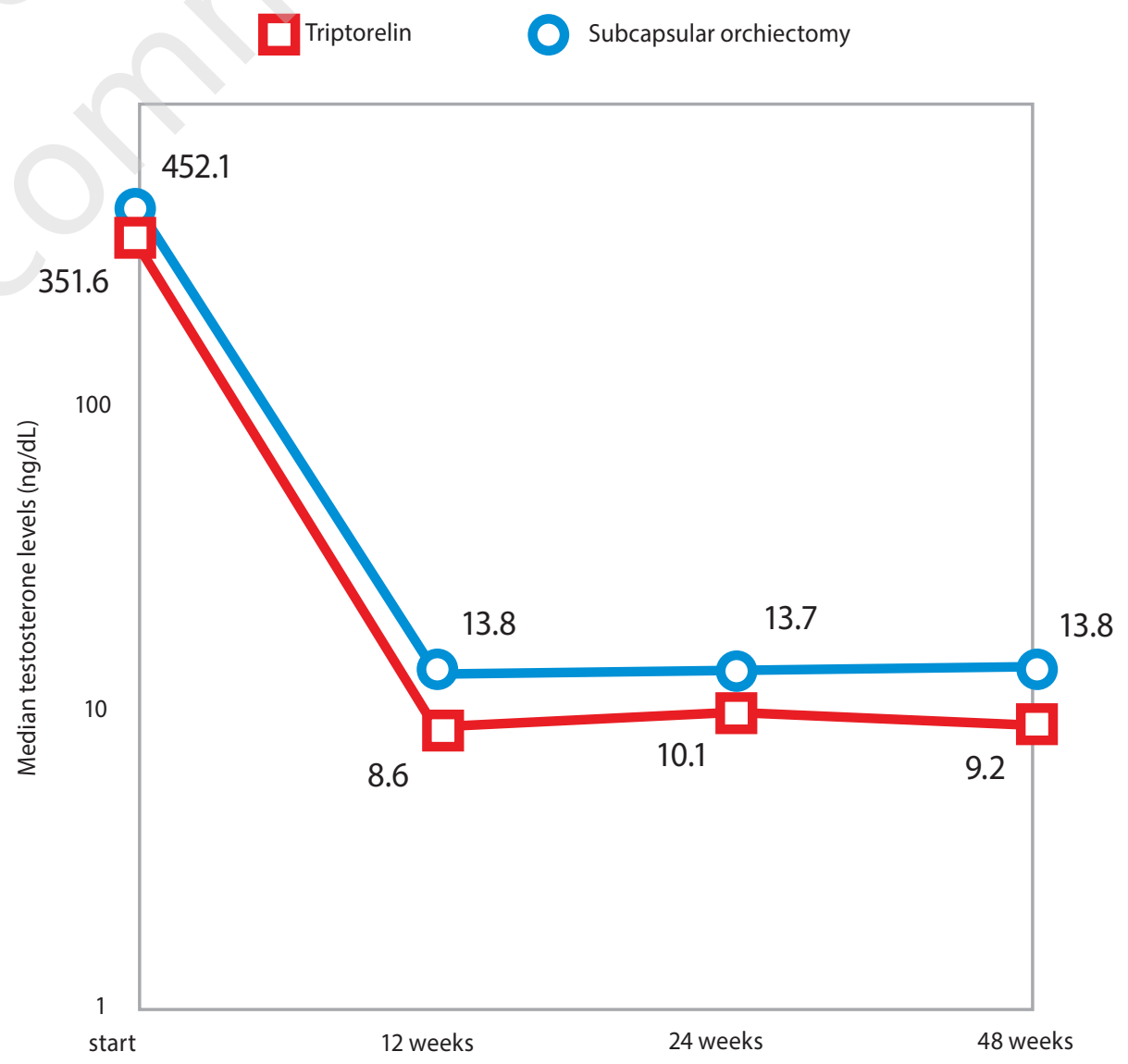


The castrate testosterone concentration was achieved a little faster in the leuprorelin group, but this percentage equaled after the second month of treatment and was finally over $97 \%$ in both groups. Maintenance of castration was evident in both groups during the nine-month control. Both treatments were also equivalent in terms of PSA reduction. However, overall survival during the study was significantly better with triptorelin than leuprorelin (97.0\% vs. $90.5 \%)$. Formulas with a longer release period of six months are available for both these drug and it was emphasized, that there is a need to construct an adequate clinical trial comparing these preparations [64].

To compare the efficacy of different LHRH analogues, due to a shortage of randomized prospective studies, it seems the only way to resort to retrospective studies. This year, the results of a retrospective study were published covering 125 patients with PCa treated with three-month release analogues [65]. Of the men included into the study, $35 \%, 47 \%$ and $18 \%$ of them received triptorelin, goserelin and leuprorelin, respectively. All three com- pared analogs showed similar efficacy measured by achieving the castrate level of testosterone $(<50 \mathrm{ng} / \mathrm{dl})$. However, during the nine-month therapy, the lowest mean testosterone levels were reached with triptorelin (fig. 5). Assuming a testosterone threshold of $<10 \mathrm{ng} / \mathrm{dl}$, particular LHRH analogues achieved it in the percentage: triptorelin in $93.2 \%$, leuprorelin in $86.4 \%$, and goserelin in $54.2 \%$. Testosterone levels achieved at subsequent three-month intervals were significantly lower during treatment with triptorelin than with goserelin, both as monotherapy and in the use of complete androgen blockade (CAB).

Recently, the set of drugs available in Poland in ADT has been expanded to include the LHRH antagonist - degarelix. The document that most fully assesses the effectiveness of a new drug compared to LHRH agonists is the health technology assessment report prepared at the request of NICE (National Institute for Health and Care Excellence) [66]. Among the studies considered, the key finding was that the use of degarelix brought no less benefit (non-inferiority trial) than leuprorelin treatment in achieving

FIGURE 5.

The mean testosterone levels in patients during antiandrogen therapy using triptorelin (red squares), leuprorelin (green circles) and goserelin (yellow triangles). Modified after [65].

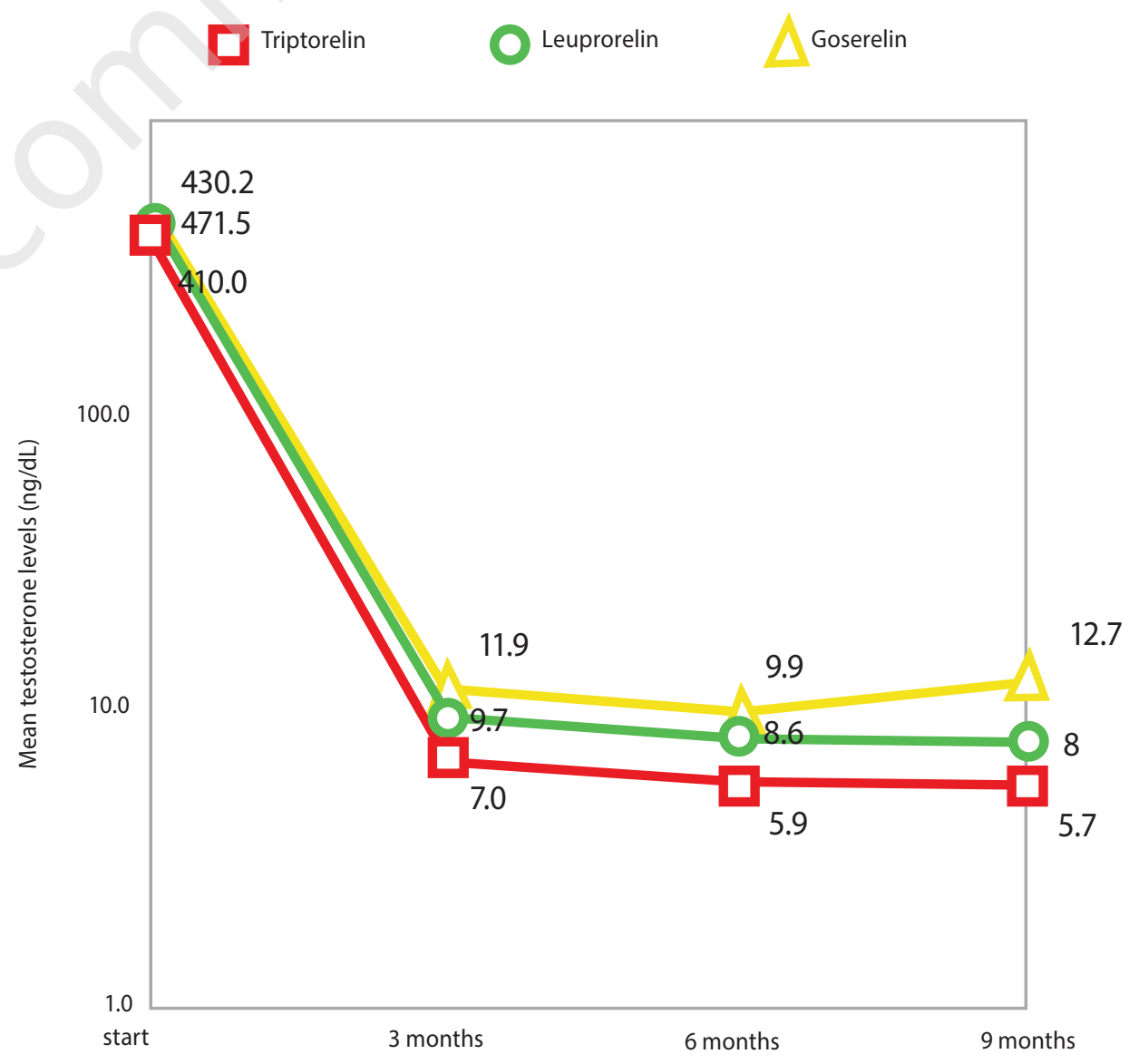


the castrate level of testosterone, with degarelix allowing a faster reduction in PSA levels. Based on the assumption that there is no evidence that the effectiveness of individual LHRH analogues is equal, it was necessary to make a summary for each of these drugs separately. Therefore, for the purposes of the report, network meta-analysis of six randomized trials comparing degarelix with LHRH analogues was performed. As no studies are available to confront degarelix with triptorelin, an indirect comparison was performed. Although the study did not show significant differences in overall survival between the drugs used, the meta-analysis graph clearly presented that triptorelin as the only LHRH analogue showed lower mortality than degarelix [66].

Although estrogen therapy is no longer the first-line treatment in advanced $\mathrm{PCa}$, it should be mentioned due to numerous studies comparing their effectiveness with triptorelin. In the SPCG-5 study, estrogen therapy was compared to $C A B$ based on flutamide and triptorelin ( $65 \%$ of patients) or orchidectomy (35\% of patients) [67]. In patients with metastatic PCa, there was no difference in overall or cancer-specific survival between both treatments. However, a significantly higher risk of cardiovascular complications was observed in men treated with estrogens.

The use of nonsteroidal antiandrogens (flutamide or bicalutamide) as monotherapy is no longer recommended for metastatic PCa [8]. However, antiandrogens still find their place in combination with LHRH analogues in two cases: the use of CAB or as an additional therapy to prevent a transient testosterone flare. There are no randomized studies available in which triptorelin would be tested in combination with any of the nonsteroidal antiandrogens in $C A B$ [68]. In single-arm studies, possible benefits of adding flutamide to $A D T$, including triptorelin, were shown in the form of better clinical response and even reduction of mortality [69]. However, the benefits of using CAB compared to standard ADT are between $0 \%$ and $5 \%$ and remain a highly controversial issue [68].

\section{ADVERSE EFFECTS AND SAFETY OF ADMINISTRATION}

Due to the widespread use of LHRH analogues, a number of studies specifically dedicated to the safety profile of these drugs have been carried out. Most of the observed adverse effects are a consequence of the mechanism of action of these drugs and the inhibitory effect on the hypothalamic-pituitary-testicular axis [19-22]. One of the potentially dangerous phenomena that is associated with the pharmacodynamic properties of LHRH analogues is a transient testosterone flare after the first dose. To prevent the potentially dangerous consequences of this phenome- non, it is currently recommended to co-administer antiandrogen for up to four weeks. It has been shown that starting administration of flutamide one week before the begining of triptorelin therapy enables to effectively reduce the consequences of flareup [69].

The most common side effects during LHRH analogue therapy are hot flushes. In the aforementioned SPCG-5 study (Scandinavian Prostatic Cancer Group), the incidence of hot flushes was significantly higher in the group of patients undergoing $C A B$ (74.3\%) than among patients treated with estrogens (30.1\%), which underlines the severity of this problem in case of ADT [70]. In the CAB group, 35\% were patients treated with triptorelin in combination with flutamide, but the incidence of hot flushes did not differ significantly from the incidence of this phenomenon among patients undergoing orchiectomy. Moreover, more than a third of patients undergoing $C A B$ reported four or more hot flushes, more than half of the patients felt this symptom was troublesome, of which $11.3 \%$ to a large extent. In none of the patients hot flushes resolved during one and a half year follow-up, however their frequency decreased over time.

Particular forms of ADT, due to different mechanisms leading to castration, cause various endocrine and metabolic changes. Epidemiological studies indicate a relationship between ADT and an increased risk of metabolic syndrome, diabetes and coronary heart disease [71]. Patients should be informed of such eventualities and monitored for signs of these diseases. Referring again to the results of the SPCG-5 study, CAB therapy is associated with an increased risk of a cardiovascular incident among predisposed patients who have already had a similar incident in the past, in particular cerebral ischemia [72]. By leading to hypoandrogenism, individual forms of ADT affect the levels of other hormones differently, for example, estrogen levels [73]. Combination therapy of triptorelin with flutamide $(C A B)$ causes a decrease in triglycerides and apolipoprotein B in the VLDL (very low density lipoprotein) fraction, an increase in the concentration of apolipoprotein B in LDL (low density lipoprotein) and an increase in the concentration of cholesterol and apolipoprotein A-I in the HDL fraction (high density lipoprotein). Changes in the lipid profile are definitely more favorable than those caused by other forms of ADT, such as orchiectomy or estrogens. This may be due to less pronounced $C A B$ suppression of estrogen and additional suppression of adrenal androgens by flutamide.

In a randomized clinical trial comparing subcapsular orchiectomy with six-month release triptorelin authors focused on studying metabolic changes in patients undergoing various forms 
of ADT [74]. One year of follow-up showed no difference in glucose intolerance. However, men undergoing orchiectomy experienced greater weight gain and had more total body fat (over $3 \mathrm{~kg}$ and over $2 \mathrm{~kg}$, respectively) than those treated with triptorelin. Weight gain was correlated with the development of insulin resistance. ADT leads to changes in body composition that may predispose to insulin resistance and an increase in total, $\mathrm{HDL}$ and LDL cholesterol.

A less defined problem is the loss of bone mineral density due to accelerated bone turnover caused by ADT [75]. This may in turn predispose to faster development of osteoporosis and osteoporotic fractures imitating pathological fractures in patients with metastatic PCa. Loss of bone mineral density by about $6 \%$ was found during one and a half year therapy with monthly release triptorelin. A retrospective analysis showed that treatment with LHRH analogues is associated with an increased risk of bone fractures [76].

Due to conflicting results of studies, the potential impact of ADT on cognitive functions also raises controversies [77]. However, a recent analysis of the Food and Drug Administration (FDA) database on adverse drug reactions showed no association of any of the drugs used in ADT with Alzheimer's disease or cognitive impairment. It has not been shown that triptorelin is the causative agent of any case of the abovementioned disorders.

\section{CLOSING COMMENTS}

Features that the clinician should be guided by choosing the most appropriate drug in ADT is to achieve quickly and effectively maintain the state of castration while minimizing adverse effects and maintaining convenience of administration. During treatment of patients with hormone-sensitive advanced $\mathrm{PCa}$, testosterone and PSA levels play a key role in monitoring the effectiveness of therapy [8]. There are ongoing discussions about the castrate testosterone concentration established years ago, which by definition is $<50 \mathrm{ng} / \mathrm{dl}$ [46]. It has been customarily adopted as the concentration obtained after orchiectomy and a significant proportion of the studies on the effectiveness of ADT refer to it. However, with the improvement of diagnostic methods, it turned out that the castrate testosterone concentration obtained after bilateral orchiectomy is significantly lower and is $<20 \mathrm{ng} / \mathrm{dl}$ [78]. All forms of triptorelin achieve standard castration testosterone levels with almost $100 \%$ efficacy $(96-100 \%)[44,47,49]$. Moreover, a lower recommended castration level of testosterone $<20 \mathrm{ng} / \mathrm{dl}$ is achieved in over $90 \%$ of men treated with triptorelin $[48,65]$. These observations are important in light of the results of studies showing that lowering testosterone levels to the lowest possible values may translate into overall survival of patients undergoing $\operatorname{ADT}[79,80]$. Of the most frequently used LHRH analogues, triptorelin reduces testosterone levels to the lowest levels [65]. In this respect, triptorelin is even more effective than subcapsular orchiectomy, resulting in a $29 \%$ lower testosterone concentration [59].

Considering the efficacy of sustained-release formulations, it is particularly important to maintain the castrate level of testosterone until the next dose is given. The phenomenon of escape of testosterone, which means a sudden increase in its concentration despite the continuation of therapy is extremely unfavorable, because it shortens the PSA progression-free survival [81]. This phenomenon may affect even one in four patients treated with LHRH analogues who develops testosterone levels $>50 \mathrm{ng} /$ dl despite therapy. Phase I-III studies showed no escape of testosterone in any of the men treated with one- or three-month triptorelin preparation $[43,44]$. This phenomenon was detectable only in the study of the six-month release formulation, in which the increase in testosterone level resulted in an increase in PSA in only three patients (2.5\%) [45]. The clinical significance of testosterone escape without an increase in PSA has not been fully understood.

Another important parameter is the time to achieve castration. Similarly to other LHRH analogues, initiation of triptorelin treatment is associated with a transient flare-up of testosterone, followed by a decrease to castration values within three weeks, as a results of its effect on the hypothalamic-pituitary-gonadal axis $[19-22,43,45]$. The addition of flutamide to triptorelin at the beginning of therapy makes it possible to effectively prevent this phenomenon $[8,69]$. In a randomized study, triptorelin achieved castration slightly slower than leuprorelin, but ultimately the percentage of men with the castrate level of testosterone was similar at the end of the second month of treatment. In the same study, men treated with triptorelin showed significantly better overall survival than those treated with leuprorelin [63]. In the context of pharmacodynamics, it is worth noting that degarelix leads to faster reduction of testosterone levels without flare-up phenomenon, which is due to its antagonistic activity toward LHRH receptor. However, the benefits of using LHRH antagonist should be balanced with the cost-effectiveness of such treatment and the involvement of staff in its monthly administration [66]. In addition, the graph comparing degarelix with LHRH analogues indicates that despite the lack of statistical significance in overall survival, triptorelin treatment alone was associated with lower mortality than degarelix [66]. 
Orchiectomy also allows to immediately reach the castrate level of testosterone. In studies comparing surgical treatment with triptorelin, castration was achieved and maintained equally effectively in both groups one month after starting treatment [56-58]. Subcapsular orchiectomy appears to be less effective, as patients achieve higher testosterone levels than those treated with triptorelin [59]. No less important issue may be a smaller psychological burden among men treated with triptorelin. In addition, triptorelin-based $C A B$ does not differ from orchiectomy in terms of the most common adverse effect, i.e. hot flashes [70]. Moreover, as a result of a different mechanism of obtaining castration, surgical treatment leads to more profound metabolic changes than after triptorelin, which may predispose to insulin resistance and changes in lipids [73, 74]. Orchiectomy, like any surgical treatment, is associated with the necessity of hospitalization, the risk associated with anesthesia, and possible postoperative complications (hematoma in over $20 \%$ of patients) [59]. Surgical castration is also irreversible.

The main limitation of the our study is a clear shortage in the literature of randomized studies that would compare the effec- tiveness of triptorelin with other LHRH analogues. The cost analysis of individual forms of ADT compared to sustained-release triptorelin formulations is also outside the scope of this review. A number of issues related to the role of triptorelin as a combined treatment with radiotherapy were also not raised.

Considering the issues mentioned above, the conclusion is that the decision on the selection of the most appropriate ADT method should be made together with the patient properly informed about the advantages and disadvantages of each treatment option. Of these, triptorelin occupies a high place in the treatment of advanced PCa supported by a large amount of good quality evidence of its effectiveness. The efficacy of triptorelin in achieving castration turns out to be comparable or superior to other ADT methods. In addition, having triptorelin in forms with different release times, one can properly adapt the therapy to the needs of the patient without worrying about safety, because each of these preparations has been separately tested for effectiveness. In the era of the development of new therapies in the treatment of advanced PCa and CRPC stage, classic ADT is an indispensable basis for this management.

\section{References}

1. Bray F, Ferlay J, Soerjomataram I et al. Global cancer statistics 2018: GLOBOCAN estimates of incidence and mortality worldwide for 36 cancers in 185 countries. CA Cancer J Clin. 2018; 68(6): 394-424.

2. Potosky AL. The role of increasing detection in the rising incidence of prostate cancer. JAMA 1995; 273(7): 548-52.

3. Ilic D, Neuberger MM, Djulbegovic M et al. Screening for prostate cancer. Cochrane database Syst Rev 2013; Issue 1. Art. No.: CD004720.

4. Siegel RL, Miller KD, Jemal A. Cancer statistics, 2019. CA Cancer J Clin 2019; 69(1): 7-34.

5. Dall'Era MA, deVere-White R, Rodriguez D et al. Changing Incidence of Metastatic Prostate Cancer by Race and Age, 1988-2015. Eur Urol Focus 2018.

6. Green SM, Mostaghel EA, Nelson PS. Androgen action and metabolism in prostate cancer. Mol Cell Endocrinol 2012; 360(1-2): 3-13.

7. Pagliarulo V, Bracarda S, Eisenberger MA et al. Contemporary role of androgen deprivation therapy for prostate cancer. Eur Urol 2012; 61(1): 11-25.

8. Mottet N, van den Bergh RCN, Briers E et al. EAU-ESTRO-ESUR-SIOG Guidelines on Prostate Cancer 2018. In: European Association of Urology Guidelines 2018 Edition [Internet]. Arnhem, The Netherlands: European Association of Urology Guidelines Office; 2018.

9. Dobruch J, Borówka A.,"Back bone therapy” w leczeniu chorych na raka stercza opornego na wytrzebienie. Przegląd Urologiczny 2015; 1 (89): 28-30.

10. Siddiqui ZA, Krauss DJ. Adjuvant androgen deprivation therapy for prostate cancer treated with radiation therapy. Transl Androl Urol $2018 ; 7(3)$ : 378-89.

11. Kadar T, Redding TW, Ben-David M et al. Receptors for prolactin, somatostatin, and luteinizing hormone-releasing hormone in experimental prostate cancer after treatment with analogs of luteinizing hormone-releasing hormone and somatostatin. Proc Natl Acad Sci U S A 1988; 85: 890-94.

12. Kakar SS, Musgrove LC, Devor DC et al. Cloning, sequencing, and expression of human gonadotropin releasing hormone (GnRH) receptor. Biochem Biophys Res Commun 1992; 189(1): 289-95.

13. Medycyna Praktyczna Indeks [Internet]. Medycyna Praktyczna; c1996-2019 [cytowane 5 września 2019] [online: https://indeks.mp.pl/leki/subst. php?id=816\&rfbl=1].

14. Tornoe CW, Agerso H, Senderovitz T et al. Population pharmacokinetic/pharmacodynamic (PK/PD) modelling of the hypothalamic-pituitary-gonadal axis following treatment with GnRH analogues. Br J Clin Pharmacol 2007; 63(6): 648-64.

15. Klippel KF, Winkler CJ, Jocham D et al. [Effectiveness and tolerance of 1 dosage forms (subcutaneous and intramuscular) of decapeptyl depot in patients with advanced prostate carcinoma]. Urologe A 1999; 38(3): 270-75.

16. Szymańska E, Winnicka K. Nowoczesna postać leku do oczu o kontrolowanym uwalnianiu. Farm Pol 2009; 65(5): 378-86.

17. PubChem compound summary triptorelin [Internet]. US National Library of Medicine - National Center for Biotechnology Information [cytowane 5 września 2019] [online: https://pubchem.ncbi.nlm.nih.gov/compound/Triptorelin\#section=Pharmacology].

18. Paz-Bouza Jl, Schor NA, Monje E et al. Histological findings in the rat prostate cancer model during treatment with a luteinizing hormone-releasing hormone agonist and novantrone. Prostate 1987.

19. Charakterystyka produktu leczniczego Diphereline SR 3,75; 3,75 mg; proszek i rozpuszczalnik do sporządzania zawiesiny o przedłużonym uwalnianiu do wstrzykiwań [online: http://leki.urpl.gov.pl/files/43_Diphereline_SR_3_75_prosz_rozp_sporz_zaw_przedl_uwaln_wstrzyk_3_75_ mg_4869.pdf].

20. Charakterystyka produktu leczniczego Decapeptyl Depot; 3,75 mg; proszek i rozpuszczalnik do sporządzania zawiesiny do wstrzykiwań [online: http://leki.urpl.gov.pl/files/Decapeptyl_Depot_3_75mg.pdf]. 
21. Charakterystyka produktu leczniczego Diphereline SR 11,25 mg; 11,25 mg; proszek i rozpuszczalnik do sporządzania zawiesiny o przedłużonym uwalnianiu do wstrzykiwań [online: http://leki.urpl.gov.pl/files/43_Diphereline_SR_11_25_mg_prosz_rozp_sporz_zaw_przed_uwaln_wstrzyk_11_25mg.pdf].

22. Charakterystyka produktu leczniczego Diphereline SR $22,5 \mathrm{mg}, 22,5 \mathrm{mg}$, proszek i rozpuszczalnik do sporządzenia zawiesiny do wstrzykiwań, o przedłużonym uwalnianiu [online: https://gdziepolek.blob.core.windows.net/product-documents/doc84495/diphereline-sr-22-5-mg-dokument.pdf].

23. Han J, Zhang S, Liu W et al. An analytical strategy to characterize the pharmacokinetics and pharmacodynamics of triptorelin in rats based on simultaneous LC-MS/MS analysis of triptorelin and endogenous testosterone in rat plasma. Anal Bioanal Chem 2014; 406(9-10): 2457-65.

24. Gonzalez-Barcena D, Perez-Sanchez PL, Graef A et al. Inhibition of the pituitary-gonadal axis by a single intramuscular administration of D-Trp-6-L$\mathrm{H}-\mathrm{RH}$ (decapeptyl) in a sustained-release formulation in patients with prostatic carcinoma. Prostate 1989; 14(4): $291-300$.

25. Romero E, Velez de Mendizabal N, Cendros JM et al. Pharmacokinetic/pharmacodynamic model of the testosterone effects of triptorelin administered in sustained release formulations in patients with prostate cancer. J Pharmacol Exp Ther 2012; 342(3): 788-98.

26. Szende B, Lovász S, Farid P et al. Apoptosis in Prostate Carcinomas after Short-Term Treatment with Decapeptyl. Ann N Y Acad Sci 2003; 1010: 784-88.

27. Lee LT, Schally AV, Liebow C et al. Dephosphorylation of cancer protein by tyrosine phosphatases in response to analogs of luteinizing hormone-releasing hormone and somatostatin. Anticancer Res 2008; 28(5A): 2599-605.

28. Pinski J, Reile $\mathrm{H}, \mathrm{Halmos} \mathrm{G}$ et al. Inhibitory effects of analogs of luteinizing hormone-releasing hormone on the growth of the androgen-independent dunning R-3327-AT-1 rat prostate cancer. Int J Cancer 1994. DOI: 10.1002/ijc.2910590112.

29. Jungwirth A, Schally AV, Pinski J et al. Inhibition of in vivo proliferation of androgen-independent prostate cancers by an antagonist of growth hormone-releasing hormone. Br J Cancer 1997; 75(11): 1585-92.

30. Lamharzi N, Halmos G, Jungwirth A et al. Decrease in the level and mRNA expression of LH-RH and EGF receptors after treatment with LH-RH antagonist Cetrorelix in DU-145 prostate tumor xenografts in nude mice. Int J Oncol 1998; 13(3):429-35.

31. Szepeshazi K, Korkut E, Schally AV. Decrease in the AgNOR number in dunning R3327 prostate cancers after treatment with an agonist and antagonist of luteinizing hormone-releasing hormone. Am J Pathol 1991; 138(5): 1273-77.

32. Eicke N, Gunthert AR, Viereck V et al. GnRH-II receptor-like antigenicity in human placenta and in cancers of the human reproductive organs. Eur J Endocrinol 2005; 153(4): 605-12.

33. Schally AV, Redding TW. Somatostatin analogs as adjuncts to agonists of luteinizing hormone-releasing hormone in the treatment of experimental prostate cancer. Proc Natl Acad Sci U S A 1987; 84(20): 7275-9.

34. Qayum A, Waxman J, Gullick W et al. The effects of gonadotrophin releasing hormone analogues in prostate cancer are mediated through specific tumour receptors. Br J Cancer 1990; 62(1): 96-9.

35. Redding TW, Schally AV. Inhibition of the pituitary-gonadal axis in nude male mice by continuous administration of LHRH agonists and antagonists. J Endocrinol 1990; 126(2): 309-15.

36. Milovanovic SR, Radulovic S, Groot K et al. Inhibition of growth of PC-82 human prostate cancer line xenografts in nude mice by bombesin antagonist RC-3095 or combination of agonist [D-Trp6]-luteinizing hormone-releasing hormone and somatostatin analog RC-160. Prostate 1992; 20(4): 269-80.

37. Paz-Bouza Jl, Schor NA, Monje E et al. Histological findings in the rat prostate cancer model during treatment with a luteinizing hormone-releasing hormone agonist and novantrone. Prostate 1987; 10(4): 291-302.

38. Zalatnai A, Paz-Bouza Jl, Redding TW et al. Histologic changes in the rat prostate cancer model after treatment with somatostatin analogs and DTrp-6-LH-RH. Prostate 1988; 12(1): 85-98.

39. Hellstrom M, Ranefall $\mathrm{P}$, Wester $\mathrm{K}$ et al. Effect of androgen deprivation on epithelial and mesenchymal tissue components in localized prostate cancer. Br J Urol. 1997; 79(3): 421-6.

40. Boccardo F, Giuliani L, Santi L. D-Trp-6-LH-RH treatment of advanced prostatic cancer. (London, England) 1986; 1: 621.

41. Boccardo F, Decensi A, Guarneri D et al. Long-term results with a long-acting formulation of D-TRP-6 LH-RH in patients with prostate cancer: an Italian prostatic cancer project (P.O.N.CA.P.) study. Prostate 1987; 11(3): 243-55.

42. Rolandi E, Franceschini R, Giberti $C$ et al. Sustained impairment of pituitary and testicular function in prostatic cancer patients treated with a depot form of a GnRH agonist. Horm Res 1988; 30(1): 22-5.

43. Bouchot $\mathrm{O}$, Soret JY, Jacqmin D et al. Three-month sustained-release form of triptorelin in patients with advanced prostatic adenocarcinoma: results of an open pharmacodynamic and pharmacokinetic multicenter study. Horm Res 1998; 50(2): 89-93.

44. Teillac P, Heyns CF, Kaisary AV et al. Pharmacodynamic equivalence of a decapeptyl 3-month SR formulation with the 28-day SR formulation in patients with advanced prostate cancer. Horm Res 2004; 62(5): 252-8.

45. Lundstrom EA, Rencken RK, van Wyk JH et al. Triptorelin 6-month formulation in the management of patients with locally advanced and metastatic prostate cancer: an open-label, non-comparative, multicentre, phase III study. Clin Drug Investig 2009; $29(12): 757-65$.

46. Zlotta A, Debruyne FMJ. Expert opinion on optimal testosterone control in prostate cancer. Eur Urol Suppl 2005; 4(8): 37-41.

47. Lebret $\mathrm{T}$, Rouanne $\mathrm{M}$, Hublarov $\mathrm{O}$ et al. Efficacy of triptorelin pamoate $11.25 \mathrm{mg}$ administered subcutaneously for achieving medical castration levels of testosterone in patients with locally advanced or metastatic prostate cancer. Ther Adv Urol 2015; 7(3): 125-34.

48. Breul J, Lundstrom E, Purcea D et al. Efficacy of Testosterone Suppression with Sustained-Release Triptorelin in Advanced Prostate Cancer. Adv Ther 2017; 34(2): 513-23.

49. Kao CC, Chang YH, Wu T et al. Open, multi-center, phase IV study to assess the efficacy and tolerability of triptorelin in Taiwanese patients with advanced prostate cancer. J Chin Med Assoc 2012; 75(6): 255-61.

50. Klippel KF, Winkler CJ, Jocham D et al. [Effectiveness and tolerance of 1 dosage forms (subcutaneous and intramuscular) of decapeptyl depot in patients with advanced prostate carcinoma]. Urologe A 1999; 38(3): 270-5.

51. Martinez-Pineiro L, Schalken JA, Cabri P et al. Evaluation of urinary prostate cancer antigen-3 (PCA3) and TMPRSS2-ERG score changes when starting androgen-deprivation therapy with triptorelin 6-month formulation in patients with locally advanced and metastatic prostate cancer. BJU Int 2014; 114(4): 608-16.

52. de la Taille A, Martinez-Pineiro L, Cabri P et al. Factors predicting progression to castrate-resistant prostate cancer in patients with advanced prostate cancer receiving long-term androgen-deprivation therapy. BJU Int 2017; 119(1): 74-81.

53. Heidenreich A, Porres D, Epplen R et al. [Change of the LHRH analogue in progressive castration-refractory prostate cancer]. Urologe A 2012; 51(9): 1282-7.

54. Calais da Silva F, Calais da Silva FM, Goncalves F et al. Locally advanced and metastatic prostate cancer treated with intermittent androgen monotherapy or maximal androgen blockade: results from a randomised phase 3 study by the South European Uroncological Group. Eur Urol 2014; 66(2): 232-9.

55. Mathe G, Schally AV, Comaru-Schally AM et al. Phase II trial with D-Trp-6-LH-RH in prostatic carcinoma: comparison with other hormonal agents. Prostate 1986; 9(4): 327-42.

56. Parmar H, Phillips RH, Lightman SL et al. Early tumor exacerbation in patients treated with long acting analogues of gonadotrophin releasing hormone. British Medical Journal (Clinical research ed.) 1985; 291: 1645.

57. Parmar H, Edwards L, Phillips RH et al. Orchiectomy versus long-acting D-Trp-6-LHRH in advanced prostatic cancer. Br J Urol 1987; 59(3): 248-54. 
58. Parmar H, Phillips RH, Lightman SL et al. How would you like to have an orchidectomy for advanced prostatic cancer? Am J Clin Oncol 1988; 11 Suppl 2: S160-8.

59. Ostergren PB, Kistorp C, Fode M et al. Luteinizing Hormone-Releasing Hormone Agonists are Superior to Subcapsular Orchiectomy in Lowering Testosterone Levels of Men with Prostate Cancer: Results from a Randomized Clinical Trial. J Urol 2017; 197(6): 1441-7.

60. Bolton EM, Lynch T. Are all gonadotrophin-releasing hormone agonists equivalent for the treatment of prostate cancer? A systematic review. BJU Int 2018; 122(3): 371-83.

61. Kuhn JM, Abourachid $\mathrm{H}$, Brucher $\mathrm{P}$ et al. A randomized comparison of the clinical and hormonal effects of two $\mathrm{GnRH}$ agonists in patients with prostate cancer. Eur Urol 1997; 32(4): 397-403.

62. Abbou CC, Lucas C, Leblanc V. [Tolerance and clinical and biological responses during the first 6 months of treatment with 1-month sustained release LHRH agonists leuprolerin and triptolerin in patients with metastatic prostate cancer]. Prog Urol 1997; 7(6): 984-95.

63. Heyns CF, Simonin MP, Grosgurin P et al. Comparative efficacy of triptorelin pamoate and leuprolide acetate in men with advanced prostate cancer. BJU Int 2003; 92(3): 226-31.

64. Crawford ED, Phillips JM. Six-month gonadotropin releasing hormone (GnRH) agonist depots provide efficacy, safety, convenience, and comfort. Cancer Manag Res 2011; 3: 201-9.

65. Shim M, Bang WJ, Oh CY et al. Effectiveness of three different luteinizing hormone-releasing hormone agonists in the chemical castration of patients with prostate cancer: Goserelin versus triptorelin versus leuprolide. Investig Clin Urol 2019; 60(4): 244-50.

66. Uttley L, Whyte S, Gomersall T et al. Degarelix for Treating Advanced Hormone-Dependent Prostate Cancer: An Evidence Review Group Perspective of a NICE Single Technology Appraisal. Pharmacoeconomics 2017; 35(7): 717-26.

67. Hedlund PO, Henriksson P. Parenteral estrogen versus total androgen ablation in the treatment of advanced prostate carcinoma: effects on overall survival and cardiovascular mortality. The Scandinavian Prostatic Cancer Group (SPCG)-5 Trial Study. Urology 2000; 55(3): 328-33.

68. Dalesio $\mathrm{O}$, Van Tinteren $\mathrm{H}$, Clarke $\mathrm{M}$ et al. Maximum androgen blockade in advanced prostate cancer: An overview of the randomised trials. Lancet 2000; 355: 1491-8.

69. Labrie F, Dupont A, Giguere M et al. Combination therapy with flutamide and castration (orchiectomy or LHRH agonist): the minimal endocrine therapy in both untreated and previously treated patients. J Steroid Biochem 1987; 27(1-3): 525-32.

70. Spetz AC, Hammar M, Lindberg B et al. Prospective evaluation of hot flashes during treatment with parenteral estrogen or complete androgen ablation for metastatic carcinoma of the prostate. Prospective evaluation of hot flashes during treatment with parenteral estrogen or complete androgen ablation for metastatic carcinoma of the prostate. J Urol 2001; 166(2): 517-20.

71. Kintzel PE, Chase SL, Schultz LM et al. Increased risk of metabolic syndrome, diabetes mellitus, and cardiovascular disease in men receiving androgen deprivation therapy for prostate cancer. Pharmacotherapy 2008; 28(12): 1511-22.

72. Hedlund PO, Johansson R, Damber JE et al. Significance of pretreatment cardiovascular morbidity as a risk factor during treatment with parenteral oestrogen or combined androgen deprivation of 915 patients with metastasized prostate cancer: evaluation of cardiovascular events in a randomized trial. Scand J Urol Nephrol 2011;45(5): 346-53.

73. Moorjani S, Dupont A, Labrie F et al. Changes in plasma lipoproteins during various androgen suppression therapies in men with prostatic carcinoma: effects of orchiectomy, estrogen, and combination treatment with luteinizing hormone-releasing hormone agonist and flutamide. J Clin Endocrinol Metab 1988; 66(2): 314-22.

74. Ostergren PB, Kistorp C, Fode M et al. Metabolic consequences of gonadotropin-releasing hormone agonists vs orchiectomy: a randomized clinical study. BJU Int 2019; 123(4): 602-11.

75. Maillefert JF, Sibilia J, Michel F et al. Bone mineral density in men treated with synthetic gonadotropin-releasing hormone agonists for prostatic carcinoma. J Urol 1999; 161(4): 1219-22.

76. Smith MR, Boyce SP, Moyneur E et al. Risk of clinical fractures after gonadotropin-releasing hormone agonist therapy for prostate cancer. J Urol 2006; 175(1): 136-9; discussion 139.

77. Lehrer S, Rheinstein PH, Rosenzweig KE. No Relationship of Anti-Androgens to Alzheimer's Disease or Cognitive Disorder in the MedWatch Database. J Alzheimer's Dis reports 2018; 2(1): 123-7.

78. Oefelein MG, Feng A, Scolieri MJ et al. Reassessment of the definition of castrate levels of testosterone: Implications for clinical decision making. Urology 2000; 56(6): 1021-4.

79. Perachino M, Cavalli V, Bravi F. Testosterone levels in patients with metastatic prostate cancer treated with luteinizing hormone-releasing hormone therapy: prognostic significance? BJU Int 2010; 105(5): 648-51.

80. Klotz L, O'Callaghan C, Ding K et al. Nadir testosterone within first year of androgen-deprivation therapy (ADT) predicts for time to castration-resistant progression: A secondary analysis of the PR-7 trial of intermittent versus continuous ADT. J Clin Oncol 2015; 33(10): 1151-6.

81. Morote J, Orsola A, Planas J et al. Redefining Clinically Significant Castration Levels in Patients With Prostate Cancer Receiving Continuous Androgen Deprivation Therapy. J Urol 2007; 178(4 Pt 1): 1290-5.

82. Omasits $\mathrm{U}$, Ahrens $\mathrm{CH}$, Müller S et al. Protter: interactive protein feature visualization and integration with experimental proteomic data. Bioinformatics 2014; 30: 884-86.

Authors' contributions:

Mieszko Kozikowski: designing conception of the article, review of the literature, preparation and interpretation of results, preparation of tables and figures, writing the initial version of the manuscript, preparation of the final version of the manuscript, contact with the publishing house. Jakub Dobruch: designing conception of the article, developing and interpreting results, applying corrections and preparing the final version of the manuscript. Conflict of interests: None.

Financial support: None. Ethics:

The authors had full access to the data and take full responsibility for its integrity.

All authors have read and agreed with the content of the manuscript as written. This work has been carried out in accordance with The Code of Ethics of the World Medical Association (Declaration of Helsinki) for experiments involving humans. 